\title{
The Diurnal Variation of the Atmospheric Potential Gradient on the Summit of Mt. Fuji and along Its Slope.
}

\author{
By H. HATAKEYAMA \& K. UCHIKAWA \\ Meteorological Research Institute, Tokyo, and Honjō Branch \\ of the Aerological Observatory.
}

\begin{abstract}
The atmospheric potential gradient was observed on the summit of Mt. Fuji $(3778 \mathrm{~m})$, at $5.5 \mathrm{go}(2800 \mathrm{~m})$ and Gotemba $(460 \mathrm{~m})$, each during two or three days in August, 1947, and January, 1948. For this purpose, a polonium-collector was attached to one side of Shimizu's unifilar electrometer opposite to the side the microseope is fixed. This instrument was made by the Institute of Physical and Chemical Research of Japan, and it was so designed that it can be mounted on a tripod. The visual observation was made hourly or half-hourly to investigate the diurnal variation of the atmospheric potential gradient. According to the observational results, the ordinary semi-diurnal variation (i.e. two maxima and two minima) prevails at Gotemba but at Tarōbō the diurnal variation is not so conspicuous, whereas at 5.5 gō and at the summit the potential is greater in the daytime and smaller during the night. Thus it was made clear that the large semidiurnal variation of the atmospheric potential gradient shows a change in character also in the vertical direction besides the local influences due to surrounding conditions.
\end{abstract}

\section{Introduction.}

It is well known among meteorologists that the atmospheric potential gradient observed near the earth's surface shows its maximum value in the morning and in the evening. As to the cause of the phenomenon, Whipple's theory(1) that the large value of potential gradient is in connection with the turbidity of the air near the earth's surface is the most generally accepted. While for the upper atmosphere there is no observation of the diurnal variation of the potential gradient available, except some made on aeroplane ${ }^{(2,3)}$ and also by Lautner ${ }^{(4)}$ who made continuous observation, though for a short period, of the potential gradient on the summit of Zugspitze (2312 m).

Investigations, in order to separate the world-wide variation from the diurnal variation of the potential gradient near the earth's surface, have been and are still 
being done by atmospheric electricians. So it is very interesting to know how the type of the diurnal variation of the potential gradient changes with height. The authors of the present paper observed the diurnal change of the atmospheric potential gradient with a portable electrometer on the summit of Mi. Fuji $(3778 \mathrm{~m})$, at 5.5 gō $(2800 \mathrm{~m})$, Tarōbo $(1290 \mathrm{~m})$ and Gotemba $(460 \mathrm{~m})$, each during two or three days in August, 1947, and January, 1948, with Mr. S. Ohta ${ }^{(i)}$, who made observations of the condensation nuclei.

\section{Method of Observation.}

The electrometer used in this observation was Shimizu's unifilar electrometer made by the Insticute of Physical and Chemical Research. The metallic case of the electrometer and the microscope were removed from the stand and mounted on the top

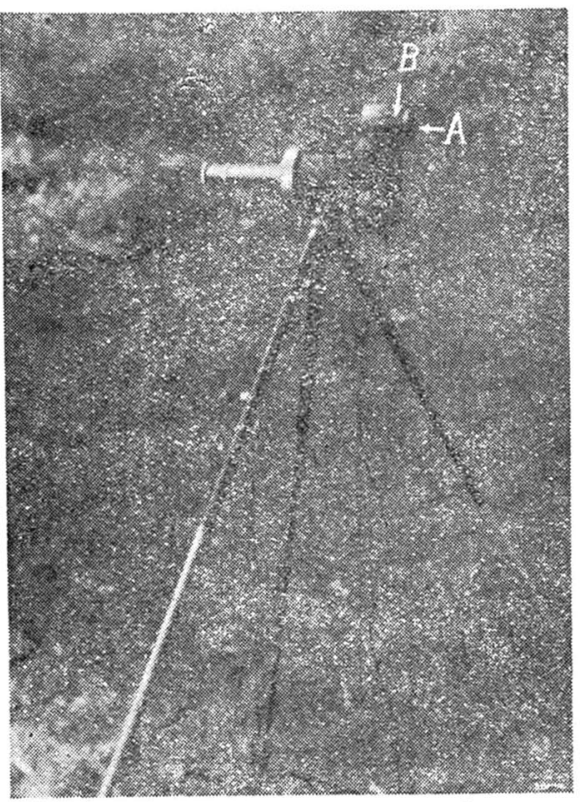

Fig. 1 Portable Electrometer A: Collector, B: Ambroid of the tripod of photograyhic camera as photographically shown in Fig. 1., in which $\mathrm{A}$ is the polonium-collector and $\mathrm{B}$ is the ambroid. The metallic case of the electrometer, the microscope, dry cells, wires are put into a sinall portable wooden box shown in the lower part of Fig. 2 with other accessories.

As shown in Fig. 1, the case of the electrometer is earthed with a thin wire and its height is about $1.2 \mathrm{~m}$ from the earth's surface. The polonium-collector is about $3 \mathrm{~cm}$ apart from the earthed case of the electrometer. When the observation is made on the plane earth's surface, the atmospheric potential gradient is obtained from the indication of the electrometer by multiply.

ing the ordinary plane reduction coefficent. An example of the coefficient is shown in Table 1, which was measured at Kashiwa race-course, Chiba Prefecture, on September, 1947.

The scenes of actual

Table 1

observation are shown in

Figs. 2 and 3. Fig. 2 shows that at Tarōbō and Fig. 3 that on the summit of $\mathrm{Mt}$. Fuji. On the summit the potential gradient is so

\begin{tabular}{c|c|l}
\hline $\begin{array}{l}\text { Height of the } \\
\text { collector }(\mathrm{m})\end{array}$ & $\begin{array}{c}\text { Coefficient of the } \\
\text { plane reduction }\end{array}$ & \multicolumn{1}{|c}{ Remarks } \\
\cline { 2 - 3 } 1.16 & 2.02 & For Taröbō and Gotemba \\
0.58 & 4.91 & For $5 . \overline{5}$ gō \\
0.34 & 7.26 & Collector on the upper corner \\
0.27 & 9.77 & Collector on the lower corner \\
\hline
\end{tabular}
large that, we can hardiy catch the image of the fiber in the field of microscope. 


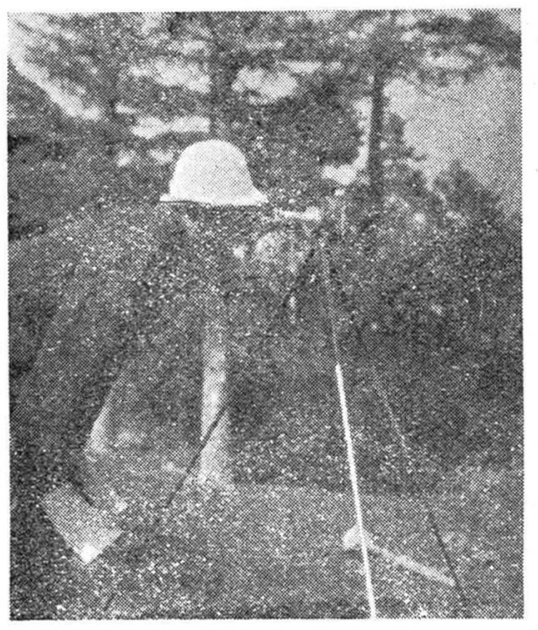

Fig. 2 'At Tarōbō

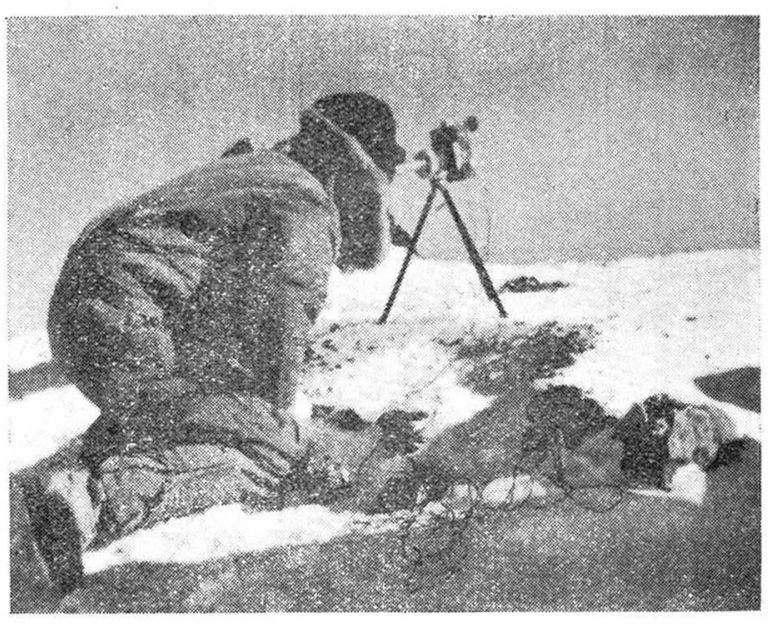

Fig. 3 On the summit of Mt. Fuji.

In the actual observation, there are growing trees in the neighbourhood of the observing spot as scen in Fig. 2, or the spot itself is a peaked summit as seen in Fig. 3. Thus another reductiou factor to reduce these topographical effects is necessary. To determine the reduction factor we have no other means than to estimate it from the position of the electrometer and the topography around it considering the equipotential surface. But we do not apply this reduction to our observations because our aim is only to clarify the type of the diurnal variation of the potential gradient.

For the observation during the night, electric torch was placed on the same side as the collector. The indication of the electrometer becomes smailer when the electric torch is brought near by. The reading of the electrometer during the night was reduced to that of the daytime by multiplying the factor duly determined.

In August, 1947, the observation was made at Tarōbō from 14h, 18th to $11 \mathrm{~h}$, 19th, at 5.5. go from $7 \mathrm{~h}, 20$ th to $8 \mathrm{~h}, 21 \mathrm{st}$, on the summit from $16 \mathrm{~h}, 21 \mathrm{st}$ to $7 \mathrm{~h}, 24 \mathrm{th}$, at $5.5 \mathrm{go}$ again from $12 \mathrm{~h}, 24$ th to $9 \mathrm{~h}, 25$ th and at Tarōbō again from $14 \mathrm{~h} 20 \mathrm{~m}$, 25th to $9 \mathrm{~h} 30 \mathrm{~m}, 26 \mathrm{th}$. The observation was made hourly in principle, and occasionally halfhourly or bi-hourly. The observation was discontinued for several hours at night for sleeping.

In December, 1947, and January, 1948, the observation was made at Gotemba from $11 \mathrm{~h}, 29 \mathrm{th}$ to $11 \mathrm{~h}, 30 \mathrm{th}$, on the summit from $17 \mathrm{~h}$, 2nd to $11 \mathrm{~h}, 4$ th, at Tarōbo from $9 \mathrm{~h}$, 6 th to $12 \mathrm{~h}, 7$ th and at Gotemba again from $15 \mathrm{~h}, 7$ th to $17 \mathrm{~h}, 8$ th.

\section{Results of Observation.}

Results of observation in Summer is shown graphically in Fig. 4 and results in Winter in Fig. 5. The abscissa is the time and the ordinate is the potential gradient expressed in volts per meter. As already mentioned the value of the potential gradient 


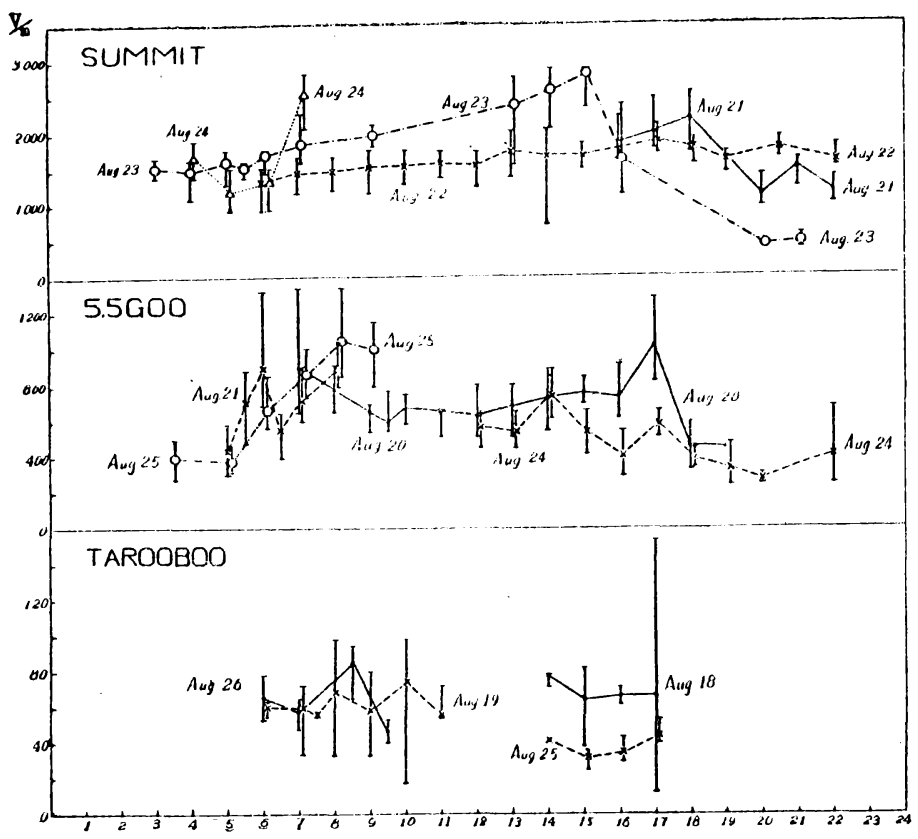

Fig. 4

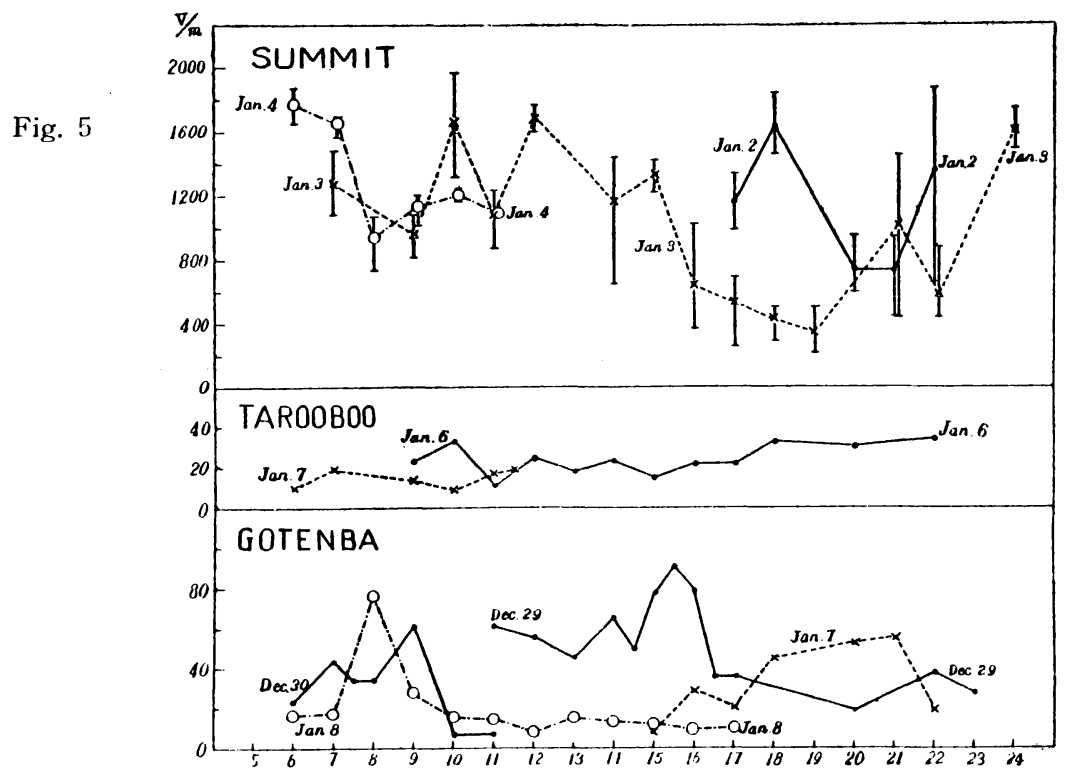

is not multiplied by the reduction factor due to the topography in the neighbourhood of the observing spot. The actual potential gradient at Gotemba and Tarōbō would be about twice as large as that shown in Figs. 4 and 5 , and that at 5.5 gō and the summit would be far smaller than that shown in the same figures. In them, the full vertical lines show the range of the fluctuations of the observed potential gradient.

On inspecting Fig. 4 and 5 we find at once that the value of potential gradient at Gotemba and Tarōbō is the same order of magnitude as at ordinary land stations and that at 5.5 gō and the summit is extraordinarily great. Perhaps this may be due 
to the pole-effect.

As to the type of the diurnal variation of the potential gradient, that at Gotemba exhibits ordinary semi-diurnal change (i.e. two maxima and two minima). One maximum is at $8 \mathrm{~h}$ or $9 \mathrm{~h}$ and the other is at $17 \mathrm{~h}$ or $18 \mathrm{~h}$. From parallel observations of other meteorological elements, it was found that these maxima have close relation with the trailing haze-layer or the coming and going of the turbid air caused by the sudden change of the wind direction.

At Tarōbo the potential gradient is almost constant through the whole day both in Summer and in Winter.

At $5.5 \mathrm{go}$ and the summit the potential gradient is greater in the daytime than in the night, being almost twice as large. The type of diurnal variation at Zugspitze already referred to is similar to those at $5.5 \mathrm{go}$ and the summit. This type of diurnal variation is considered as universal on a mountain higher than $2000 \mathrm{~m}$.

Mr. S. Ohta observed the number of the condensation nuclei at the same time with our observation of the potential gradient. According to his conclusion the number of nuclei becomes smaller as the height increases and they are most numerous just after the noon and least in the early morning. Also he concluded that this diurnal variation of the number of nuclei may be due to the transportation of the nuclei by the ascending and descending currents along the slope of the mountain.

The potential gradient becomes greater (smaller) when there comes an air current containing numerous (less) condensation nuclei, consequently less (more) small ions and having less (better) electrical conductivity. These are agreeable observational results. In the free atmosphere the range of the diurnal variation of the potential gradient will be less than that at the summit or at the side of a mountain, because in the free atmosphere, the range of the diurnal variation of the number of nuclei is considered less than that on a mountain, as Mr. Ohta estimated. These points shall be verified in the future.

In conclusion the authors wish to express their warmest thanks to Mr. S. Ohta, Mr. I. Fuzimura, Chief of Mt. Fuji Weather Station, Mr. K. Takei, Chief of Gotemba Weather Station, and other members of the station for their kindness bestowed on us.

\section{References}

(1) F.J.W. Whipple; Quart. Journ. Roy. Met. Soc., 55, 351 (1929).

(2) A. Wigand; Luftelektrische Untersuchungen bei Flugzeugaufstiegen, (1925).

(3) Ross Gunn; Journ. Appl. Phys., 19, 481 (1948).

(4) P. Lautner; Met. Zeit., 43, 488 (1926).

(5) S. Ohta; Journ. Met. Soc. Japan, 28, 188 (1950). 